УДК 37.072

\title{
ВИВЧЕННЯ ВИМОГ РОБОТОДАВЦІВ ДО ЗМІСТОВНОЇ СКЛАДОВОЇ СУКУПНОСТІ ПРОФЕСІЙНИХ КОМПЕТЕНЦІЙ МАЙБУТНІХ ІНЖЕНЕРІВ
}

\author{
Марія Миколаївна Бондар, \\ кандидат педагогічних наук, доцент \\ Національний університет біоресурсів і природокористування України, Україна. \\ ORCID: 0000-0002-8437-4602. \\ e-mail: bondar_mm@nubip.edu.ua
}

Олександра Володимирівна Плавинська

старший викладач

Сумський національний аграрний університет, Україна.

ORCID 0000-0003-2837-2087

e-mail: alekcandrawl@ukr.net.

Анотація. Підвищення якості підготовки майбутніх інженерів сфрер сільськогосподарського машинобудування та виробничої експлуатації сільськогосподарської техніки залишається актуальною проблемою національної системи освіти. Одним із шляхів вдосконалення навчального процесу $є$ тісна співпраця університетів з роботодавцями сільськогосподарського виробництва та залучення їх до активної участі у формуванні компетенцій випускників, адекватних вимогам ринку праці. 3 огляду на важливість підвищення ефективності цієї співпраці в статті досліджуються взаємопов'язані поняття «компетенція», «компетенції», «компетентність», «компетентний». Пропонується перелік компетенцій інженера. Вивчається зміст сукупності значущих для випускника компетенцій, а також досліджується їх прояви у виробничих умовах, пов'язаних з необхідністю певного часу для адаптації випускника інженерного факультету.

Основна мета дослідження - підвищити ступінь готовності студентів спеціальностей: галузеве машинобудування та агроінженерія, до швидкої адаптації в майбутній професійній діяльності. Для чого, на підставі результатів дослідження вимог роботодавців, відкоригувати змістовну складову сукупності професійних компетенцій.

Для досягнення мети в лютому 2017 року по вересень 2018 року здійснювалось експертне опитування роботодавців. Брали участь в дослідженні випускники грудня 2016 роки (78 чол.), фракультету конструювання та дизайну, а також механікотехнологічного факультету направлені на роботу в машинобудівні, дилерські, сервісні та виробничі сільськогосподарські організації різних форм власності. Результати проведеного опитування дозволили встановити саме які компетенції вимагають перегляду навчальних курсів і програм дисциплін для вдосконалення навчального процесу.

Ключові слова: компетенція, компетенції, компетентність, компетентний, інженерна освіта, навчальний процес, роботодавці.

DOI: https://doi.org/10.32845/msnau.2021.1.4

Постановка проблеми

Підвищення якості інженерної освіти, націлене на підготовку профресіоналів, які володіють сукупністю компетенцій, що повністю відповідають вимогам роботодавців [1, 2]. Світовою практикою професійної підготовки інженерно-технічних фахівців вже накопичений значний досвід. Так, Вашингтонська, Сіднейська і Дублінська угоди організацій відповідальних за акредитацію або визнання інженерних кваліфікацій вищого рівня, що об'єдналися однією метою - сприяти мобільності професіональних інженерів відповідної кваліфікації. Діяльність сторін, які підписали Угоду, зосереджена на розробці зразків профілів випускників та має на меті сприяти зростаючій глобалізації взаємного визнання інженерних кваліфікацій $[10, c .1]$

Інженери сфер сільськогосподарського машинобудування, технічного сервісу та товарного агропромислового виробництва повинні володіти не тільки професійними знаннями, вміннями і навичками, але і бути готовим до самостійного, творчого їх застосування та вдосконалення. Що, $є$ однією з важливих наукових і практичних завдань для національної системи освіти і виробничої сфери. Адже роботодавці, нерідко, стикаються з проблемою невідповідності компетенцій випускників вимогам виробництва. Що часто має місце через неузгодженість освітніх і професійних програм за якими готують майбутніх молодих фрахівців.

У зв'язку з чим, виникла необхідність у дослідженнях, присвячених з'ясуванню ступеню готовності випускників інженерних факультетів аграрних вищих навчальних закладів до виробничої діяльності. Ефективним механізмом вдосконалення навчального процесу $-€$ тісна співпраця університетів з роботодавцями, й у першу чергу, для обґрунтування змістовної складової сукупності необхідних компетенцій з подальшим формуванням та узгодженням з ними професійних, освітніх стандартів сучасної інженерної підготовки [1, 2].

\section{Аналіз останніх досліджень}

Вивчення досліджень і публікацій, що присвячені проблемам визначення компетенцій випускників вищих професійних навчальних закладів та їх відповідності вимогам роботодавців дозволили сфрормувати основний висновок про незавершеність дискусії щодо деффініцій, термінологій, значень, структурних елементів та інших категорій наукової проблем наповнення змістом компетенцій випускника вищої школи.

У зв'язку з чим, показово цікавим виявилося дослідження [3] (Tahirsylaj, Armend; Sundberg, Daniel) де авторами виконана величезна наукова робота що репрезентує систематичний огляд досліджень у якому розглянуті 84 наукові 
статті. Огляд мав за мету узагальнити сучасний рівень досліджень, орієнтованих на освіту і навчальні програми, що торкаються поняття компетенцій та охоплюють період у 20 років — починаючи з 1997 по 2017 рік.

На підставі зазначеного огляду, автори припустили, що існує два різних позначення «компетентностей» в освіті [3]. А саме: з теоретичної точки зору компетентність задумана як когнітивна структура, що сприяє певній поведінці; з операційній точки зору, компетенції, припускають автори, охоплюють широкий спектр навичок і поводжень вищого порядку, що представляють здатність справлятися зі складними, непередбачуваними ситуаціями; це оперативне визначення включає знання, навички та стратегічне мислення, а також передбачає цілеспрямоване й свідоме прийняття виважених рішень $[4$, c.80].

Також, компетентність визначається як інтеграція знань умінь і поглядів, що дозволяє особистості виконувати певне завдання в нечітко визначених і унікальних середовищах $[5$, c.49].

Спільне дослідження [6] Ліхуа Цуй (LiHua Cui, Китай), ХеЧжон Кім (HyeJeong Kim, Сеул, Корея) і Де Лі (De Li, Китай) направлено на вивчення того, які чинники слід враховувати в першу чергу для розвитку основних компетенцій, необхідних в бізнесі. У дослідженні оцінювався професійний рівень і проводився аналіз відповідності вимогам на основі основних компетенцій, запропонованих проектом DeSeCo, та запитань анкети, розроблених Корейським інститутом розвитку освіти (KEDI). Основні цілі цього дослідження - сприяти адаптації студентів до професійного навчання. У цьому дослідженні брала участь обмежена кількість учасників, і на думку авторів це утруднило узагальнення результатів дослідження.

В роботі [7] (Fischer, Daniel, Barth, Matthias) авторами представлений освітній підхід з ключовими компетенціями, що включає сім загальних компетенцій. Вчені стверджують, що просування ключових компетенцій є стрижневим внеском в дискусію, оскільки не підтримує будь-яку конкретну нормативну позицію, і актуально для всіх сторін. Автори наполягають на більш всеосяжній та ефективній концепції ключових компетентностей, що виходить за рамки вузької спрямованості навчання навичкам. В роботі [7, с.197] представлена структура ключових компетенцій:

І. діяти самостійно;

1) вміння виявляти індивідуальні потреби й культурну орієнтацію;

2) вміння планувати, здійснювати й оцінювати діяльність, пов'язану зі споживанням;

II.взаємодіяти в різнорідних групах;

3) вміння критично брати на себе роль активного учасника ринку;

4) вміння повідомляти про стійке споживання;

III.використовувати інструменти в інтерактивному режимі;

5) вміння використовувати, редагувати та ділитися різними формами знань;

6) уміння використовувати інформаційні та комунікаційні технології в інтерактивному режимі; мозв'язок.

7) вміння мислити далекоглядно і враховувати взає-

На підставі власних досліджень авторами наводиться висновок про те, що «... звернення до компетенцій і розвитку цих компетенцій пропонує структуру, в якій ми можемо приймати обірунтовані рішення для успішного навчання. Проблемне навчання в умовах самостійної та спільної роботи з осмисленими завданнями для студентів виявилося сильним фактором, що сприяє такому навчанню" [7, с.199].

У дослідженні [8] (Riccardo Leoni) відокремлюючи результати освіти (то є дисциплінарні знання) від компетенцій, що вимагаються, автор стверджує те, що фірми в першу чергу винагороджують за компетенції і в значно меншій мірі винагороджують за самі по собі дисциплінарні знання. Культурний фон, як правило, набуває більшого значення, ніж фрормальна освіта у формуванні необхідних компетенцій. Болонський процес міг би зруйнувати цю ситуацію за умови, що він інтегрований з конструктивістським, педагогічним підходом, інструментів якого не вистачає сьогодні, але є життєво важливим в забезпеченні навчальних процесів, що дозволяють студентам здобувати і розвивати компетентності, необхідні сучасним виробничим технологіям.

Проведення опитувань за ключовими компетенціями висвітлюється в роботі [9, с.118-119] (Kihun Kim) автором наголошується, що ні одне міжнародне порівняльне дослідження чітко не визначає поняття ключової компетентності. Однак існують різні міжнародні порівняльні дослідження, спеціально спрямовані на вимір можливостей, еквівалентних ключовим компетенцій.

У дослідженні питань, пов'язаних з поняттям компетенцій в інженерній освіті не можна обійти стороною напрацювання Міжнародного інженерного альянсу (IEA) [10]. Організація заявляє про своє прагнення вдосконалювати інженерну освіту і компетентність у всьому світі. IEA об'єднує три міжнародні угоди, що стосуються забезпечення освітньої основи для професійних інженерів та інженерів технологів. Це Вашингтонська угода (1989) (Washington Accord), Сіднейська угода (2001) (Sydney Accord) і Дублінська угода (2002) (Dublin Accord). Раніш відома як Форум мобільності інженерів (EMF), Міжнародна угода професійних інженерів (IPEA), являє собою багатонаціональну угоду між інженерними організаціями, що створює основу для встановлення міжнародного стандарту компетентності професійних інженерів. Стандарт компетентностей, що застосовується, такий же, як і в угоді з інженерами АРЕС. Основна діяльність IEA [11]:

- послідовне вдосконалення стандартів інженерної освіти, тим самим сприяти мобільності випускників;

- визначення змісту стандартів інженерної освіти та професійної компетентності;

- забезпечення об'єктивної акредитації освітніх програм й оцінка компетентності випускників;

- участь в діяльності, що стосується з інженерного фаху.

Компетенції випускників, прийняті підписантами Вашингтонської угоди, є стандартом для освіти професійних інженерів з усіх інженерних спеціалізацій. Зміст компетенцій класифікує те, що повинні знати випускники, навички, які вони повинні продемонструвати, і вміння, яким вони повинні володіти. Зміст компетенцій випускників удосконалювалися більш десятиліття, і в 2013 році були прийняті як орієнтир, за яким слід оцінити еквівалентність власних стандартів з вимогами акредитації. Детальний зміст атрибутів компетенцій наведений в брошурі [11]. 
Організацією економічного співробітництва та розвитку (OECD) прийнята програма «Визначення і вибір компетенцій: теоретичні та концептуальні засади» (DeSeCo). B основу програми було закладено чотири основні заходи [12, c.19]:

- проведено аналіз існуючих (на той час) досліджень компетенцій, при цьому акцентувалася увага на те як використані визначальні поняття. В результаті виявилася значна невідповідність у поглядах, яка вказує на необхідність всеосяжного обгрунтування основ;

- здійснювалося сприяння в обґрунтуванні спільного поняття компетентності, що спрямоване на формування узгодженого розуміння ключових положень;

- на основі досліджень, спираючись на вибір, експертами встановлено початковий набір ключових компетенцій. До цього залучалися вчені, експерти з різних галузей знань, які працювали разом щоб прийти до єдиної думки і сприяти визначенню ключових компетенцій, що мають значення для освіти;

- проведені консультації країн в рамках OECD з метою перевірки того, як країнами-учасницями визначалася і відбиралася сукупність компетенцій.

У пострадянських країнах, в тому числі і в нашій країні, Національною доктриною розвитку освіти України в XXI столітті було визначено, що головною метою української системи освіти $є$ створення умов для розвитку і самореалізації кожної особистості. При цьому, науково педагогічною громадськістю, відстоюється думка про те, що підготовка кадрів, для професійної сфрери, повинна здійснюватися на позиціях компетентносного підходу. Установчими категоріями компетентносного підходу в освіті $€$ поняття компетенції та компетентності, які в педагогічній науці досить продуктивно досліджуються, але все ж - не мають однозначного змісту і визначення, часто вживаються як синоніми [13]

\section{Мета досліджень}

Визначити вимоги роботодавців до змістовної складової сукупності професійних компетенцій діючих працівників інженерно-технічних служб. На підставі результатів дослідження - переглянути та скоригувати освітні програми дисциплін професійної підготовки випускників, і тим самим - допомогти студентам факультетів машинобудування та виробничої експлуатації, поліпшити їх готовність до швидкої адаптації в майбутній професійній діяльності.

\section{Методи дослідження}

Аналіз наукової літератури, з'ясування стану розробленості проблеми, виділення структурних компонентів сукупності компетенцій випускників інженерних факультетів у аграрних навчальних закладах; абстрагування і прогнозування для визначення умов вивчення й формулювання гіпотези; моделювання - для розробки методів обґрунтування змісту сукупності компетенцій необхідних випускнику в майбутній самостійній інженерної діяльності; експертне опитування для визначення слабких місць у професійній підготовці.

\section{Новизна}

Вперше, з використанням засобів педагогічних технологій орієнтованих на поняття компетенцій в освіті, розроблена методика обґрунтування змістовної складової сукупності професійних компетенцій діючих працівників інженернотехнічних служб, що ставить собі за мету здійснення діагностики, самодіагностики і самовдосконалення, найважливішого якості університетської інженерної підготовки - готовності випускників інженерних спеціальностей до майбутньої діяльності у виробничій сфері.

\section{Результати досліджень}

Університети, що представляють сферу вищої професійної освіти та підприємства, що представляють сферу виробництва, не можуть існувати ізольовано один від одного. Виходячи з чого, ефективним механізмом вдосконалення освітнього процесу $є$ тісна співпраця університетів з роботодавцями, в нашому випадку - галузевого машинобудування і сільськогосподарського виробництва. Необхідною умовою якісної підготовки майбутніх виробничників, та дуже важливим фактором синергетичного ефекту, $€$ наявність постійного зворотного зв'язку - ефективної комунікації університету і галузі. Дуже часто така комунікація має формат залучення роботодавців до активної участі у формуванні навчальних програм, спеціальностей і спеціалізацій. При цьому, університети та виробництво стикаються з проблемою різночитання - які саме знання, вміння і навички необхідні для того щоб звести до мінімуму час адаптації випускника на виробництві. Розвиток і вдосконалення педагогічної науки й освітнього менеджменту призвело до появи нових, більш ефективних, інструментів та технологій, що дозволяють значно примножити синергетичний ефект від об'єднання зусиль університету і товаровиробників спрямованих на прискорене зростання професійної майстерності випускників, забезпечення їх мобільності в процесі освоєння інноваційних технологій. Одним з цих інструментів, що дозволяє посилити ефективний зворотний зв'язок підприємства та університету $є$ компетентнісний підхід - педагогічна технологія, орієнтована на поняття компетенцій в освіті (competence-basededucation - CBE). Поняття «профресійна компетентність» нерозривно пов'язане з саморозвитком і самоосвітою особистості, на думку Андрієвської В.В., воно визначається рівнем професійної освіти, а також - досвідом та індивідуальними здібностями людини, його прагненням до безперервного самовдосконалення та самоосвіти, творчим відношенням до справи [14, с. 25].

У процесі підготовки до дослідження, за результатами аналізу наукової літератури та з'ясування стану розробленості проблеми прийшли до рішення прийняти за основу поняття «компетенція», «компетенція і " і "компетентність" в редакції авторів [13, с.425], саме:

«... компетенція - ... заздалегідь задана вимога щодо знань і досвіду діяльності в певній сфері;

компетенції - узагальнені способи дій, що забезпечують продуктивне виконання професійної діяльності; вони включають: знання і розуміння (теоретичні знання, здатність знати і розуміти) знання як діяти (практичне оперативне застосування знань у конкретних ситуаціях); знання як бути (цінності, які є невід'ємною частиною сприйняття життя з іншими в соціальному контексті);

компетентність - це володіння компетенцією, проявляється в ефективній діяльності і включає особисте ставлення до предмета і продукту діяльності; ... є системним поняттям, має свою структуру, рівні, функції, своєрідні характеристики, властивості;

компетентним можна стати, опановуючи певні компетенції і реалізуючи їх у досвіді конкретної діяльності.» [13, c.425]. 
Використовуючи поняття компетенцій як заздалегідь задану вимогу щодо знань і досвіду діяльності в ссрері інженерії машинобудування й агроінженерії, був підготовлений перелік вимог, тобто компетенцій, зміст яких обговорювався та узгоджувався на засіданні Ради роботодавців НУБіП України [15]. 3 узгодженого переліку вибрано вісім ключових компетенцій.

3 метою оцінки ступеня виконання вимог щодо знань, умінь і досвіду практичної діяльності випускників спеціальностей - галузеве машинобудування й агроінженерія, передбачалося комплексне використання як безпосередніх, так і опосередкованих методів отримання статистичної інформації, що пояснюється різноплановістю проблеми, що досліджується та дозволяє з'ясувати суб'єктивне ставлення респондентів до тих чи інших ключових компетенцій і отримати репрезентативну інформацію, яка дозволить прийняти раціональні рішення при коригування відповідних освітніх програм. Саме дослідження проводилося в два етапи. Перший - анонімне анкетування випускників і роботодавців на другому етапі проводився експертне опитування.

На першому етапі в якості інструменту була використана анкета, а респондентами виступали діючі фахівці, які працюють на різних посадах інженери машинобудівних підприємств, дилерських центрів, організацій технічного сервісу, державні службовці різних управлінь сільського господарства, а також фахівці інженерно-технічних служб агропромислового виробництва, яким було запропоновано відповісти на питання анкети з розгорнутими відповідями на відкриті запитання а також питання з певними варіантами відповіді на них. Зміст питань стосувався сфери професійної освіти і в тому числі мотивації до професійного самонавчання та самовдосконалення у виробничій сфері. Одне з відкритих питань стосувалося думки респондента щодо понять «кваліфікований» і «компетентний» фахівець. А саме, кого респондент вважав за краще мати в своєму підпорядкуванні. При цьому давалося пояснення: «кваліфікований - (майстер) майстерний, умілий, досвідчений, практик, натренований; компетентний (майстер) обізнаний, тлумачний; (чиновник) повноправний, повноважний». Всього в опитуванні взяли участь 162 респондента . На основі обробки результатів проведеного анкетування, можемо зробити наступні висновки: 67,9\% респондентів відповіли, що воліли б компетентного фахівця, 21,6\% вважають, що краще мати кваліфікованого фрахівця, ще 11,5 \% респондентів вважають, що це ідентичні поняття.

На другому етапі дослідження, експертному опитуванні, в якості експертів виступали керівники різних організацій в підпорядкуванні яких були випускники грудня 2016 року, спеціальностей: галузеве машинобудування; агроінженерія. Всього 78 керівників щомісяця анкетувалися з лютого 2017 року по вересень 2018 року. Їм пропонувалося оцінити компетентність випускників по 12-ти бальній шкалі за сукупністю запропонованих восьми компетенцій, містять відповідний набір знань умінь і навичок. При цьому, респонденти повинні були паралельно оцінювати за тими ж параметрами свого штатного співробітника , практика, який пропрацював на підприємстві не менше трьох років і виконує аналогічні обов'язки.

Зібрані щомісяця дані піддавалися аналізу. Обробка результатів експертного опитування проводилася за допомогою математико-статистичних методів: для виявлення статистично достовірного зв'язку в показниках оцінки компетенцій необхідних випускнику для успішної адаптації на виробництві застосований аналіз кореляційних матриць (пакет SPSS); для виявлення статистично значущих рангових кореляцій - метод рангових кореляцій Спірмена; для розрахунку показників і побудови діаграм (обробка в Statistica 6 i MS Excel 2016 ). Отримані величини дисперсії і середньо-квадратичного відхилення підтверджують, що результати опитування статистично значущі.

На графріках (рис.1) відображено динаміку оцінювання компетенцій протягом дослідження.

Тут, в першу чергу, необхідно відзначити показову динаміку зростання ключових компетенцій випускників інженерних спеціальностей грудня 2016 року в порівнянні 3 штатними спеціалістами, практиками зі стажем не менші три роки.

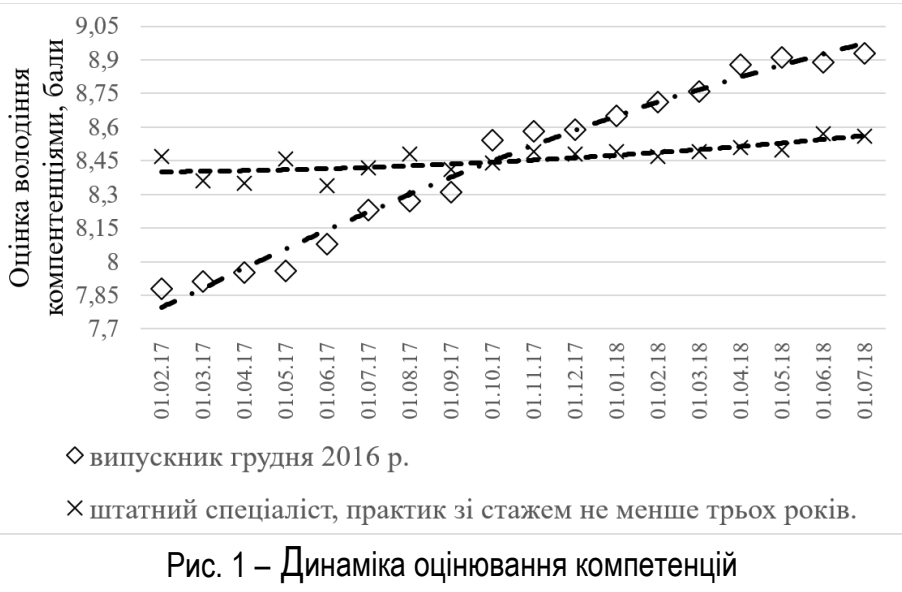

Можна припустити, що практик, що має виробничий досвід більше трьох років, залишається цілком кваліфікованим фахівцем до тих пір, поки не стикається з новими високотехнологічними засобами виробництва і йому (по ряду можливих причин, наприклад: відсутність або недостатні знання теоретичних основ інженерної підготовки, відсутність або недостатня мотивація до професійного саморозвитку; недоста- тніх комунікаційних навичок та інших факторів, що обмежують можливості самовдосконалення в його виробничої діяльності) необхідно більше часу для освоєння нових технологій, нової техніки і нових організаційних форм, що визначають потенціал в досягненні виробничих цілей, а це в кінцевому підсумку віддзеркалюється у рівні конкурентоспроможності підприємства. 
На противагу цьому випускник, що вільно володіє ключовими компетенціями та сильною мотивацією до самовдосконалення, тобто до професійного саморозвитку, досить швидко адаптується на виробництві.

Висновки та перспективи подальших досліджень

Розроблена і випробувана методика обґрунтування змістовної складової сукупності професійних компетенцій дозволила отримати результати самодіагностики, необхідні для вдосконалення програм професійної підготовки студентів інженерних спеціальностей сфери агробізнесу.

За результатами дослідження було встановлено, що випускники з високим рівнем компетентності в виробничих си- туаціях вибирають стратегії, спрямовані на вирішення проблем, вони мотивовані прагненням досягти успіху, готові до самовдосконалення.

Випускники з нижчим рівнем компетентності у виробничих ситуаціях намагаються уникати самостійного рішення виробничих проблем, і часто не розуміють та не прогнозують їх наслідків.

Приведені в статті підсумки є проміжними. Так як, головна мета дослідження - встановлення позитивної динаміки в скороченні термінів адаптації випускників в умовах виробництва, можлива на підставі результатів повторного експерименту, що враховує наслідки заявленої вище корекції програм професійної підготовки.

\section{Список використаної літератури.}

1. Nikolaenko S., Bondar M., Bulgakova O., Dukulis I. Investigation of pedagogical conditions for development of professional self-perfection skills of future agricultural engineers. Engineering for Rural Development, 19, 2020, pp. 1364-1372. http://tf.llu.lv/conference/proceedings2020/Papers/TF337.pdf

2. Nikolaenko S., Bondar M., Bulgakova O., Dukulis I. Studying requirements for substantional list of professional knowledge for students of agricultural engineering specialities. Engineering for Rural Development, 20, 2021, pp. 1519-1525. https://www.tf.llu.lv/conference/proceedings2021/Papers/TF326.pdf

3. Tahirsylaj A., Sundberg D. The unfinished business of defining competences for 21 st century curricula - a systematic research review. Curriculum Perspectives, 40 (2), 2020, pp.131-145.

4. WesterA, Wim. Competences in education: a confusion of tongues. Journal of Curriculum studies , 2001., 33.1: 75-88.

5. Egodawatte G. An analysis of the competency-based secondary mathematics curriculum in Sri Lanka. Educational Research for Policy and Practice, 13.1, 2014, pp. 45-63.

6. Cui L. The Relationship between Core Competence and Self-Efficacy for Qualitative Improvement of Industrial Technology Training. International Journal of u-and e-Service, Science and Technology, 7.1, 2014, pp. 1-8.

7. Fischer D., Barth M. Key Competencies for and beyond Sustainable Consumption an Educational Contribution to the Debate. GAIA-Ecological Perspectives for Science and Society, 23.3, 2014, pp. 193-200.

8. Leoni R. "Graduate employability and the development of competencies. The incomplete reform of the "Bologna Process", International Journal of Manpower, Vol. 35 No. 4, 2014, pp. 448-469 https://doi.org/10.1108/JMM-05-2013-0097

9. Park H., Kim K. Kim K. Youth Key Competencies in Korea. Korean Education in Changing Economic and Demographic Contexts. Education in the Asia-Pacific Region: Issues, Concerns and Prospects, vol. 23, 2014. Springer, Singapore. https://doi.org/10.1007/978-981-4451-27-7_7

10. International engineering alliance: educational accords [online] [21.03.2021] Available at: https://www.ieagreements.org/assets/Uploads/Documents/Policy/Accord-Rules-and-Procedures-July-2018-version-2019.1.pdf
11. 25 years.
Washington
Accord.
[online]
[21.03.2021]
Available
at:

https:/www.ieagreements.org/assets/Uploads/Documents/History/25YearsWashingtonAccord-A5booklet-FINAL.pdf

12. The definition and selection of key competencies: executive summary [online] [21.03.2021] Available at: http://www.oecd.org/pisa/35070367.pdf

13. Король В. П. Термінологічні аспекти формування професійної компетентності майбутнього фрахівця / В. П. Король, О. В. Марущак // Сучасні інформаційні технології та Інноваційні методики навчання в підготовці фрахівців: методологія, теорія, досвід, проблеми. - 2014. - Вип. 37. - С. 421-427. - Режим доступу http://nbuv.gov.ua/UJRN/Sitimn_2014_37_82

14. Андрієвська В.В. Професеійна компетенція : теорія і практика ї̈ оцінки на Заході. Науково-методичне забезпечення діяльності сучасної професійної школи. - Київ, 1994. - Ч. 1. - С. 25-29.

15. Рада роботодавців університету підбила підсумки 2016 року та спланувала роботу на наступний рік // ( on line ) https://nubip.edu.ua/node/28207

Bondar M.M., National University of Life and Environmental Sciences of Ukraine (Ukraine)

Plavynska O.V., Sumy National Agrarian University (Ukraine)

Studying the requirements of employers to the content component of the total of professional competencies

Improving the quality of training of engineers in the fields of agricultural engineering and industrial operation remains an urgent problem of the national education system. One of the ways to improve the educational process is close cooperation of universities with employers of agricultural production and their involvement in active participation in the formation of graduates' competencies that are adequate to the requirements of the labor market. Taking into account the importance of increasing the efficiency of this cooperation, the article examines the interrelated concepts of "competence", "competence", "competence", "competent". A list of the competencies of an engineer is proposed. The content of the set of competencies that are significant for the graduate is studied, and the time frame of their manifestation in the production environment, associated with the need for adaptation, is investigated. 
The main goal of the study is to increase the readiness of students in specialties: industrial mechanical engineering and agricultural engineering, for quick adaptation in future professional activities. Why, on the basis of the results of the study of employers' requirements, to correct the content of the set of professional competencies.

To achieve the goal, an expert survey of employers was conducted from February 2017 to September 2018. The graduates of December 2016 (78 people) from the Faculty of Construction and Design, as well as the Faculty of Mechanics and Technology, took part in the study, and were directed to work in mechanical engineering, dealer, service and production agricultural organizations of various forms of ownership. The results of the survey made it possible to establish exactly what competencies require revision of curricula and discipline programs to improve the educational process.

Key words: competence, competencies, competence, competent, engineering education, educational process, employers.

Дата надходження до редакції: 18.02.2021 